\title{
Determinants of Poverty: A Dynamic Panel Data Analysis with Controls for Income Level and Inequality
}

\author{
Kah Wei Leow ${ }^{\mathrm{a}}$ \\ Eu Chye Tan ${ }^{\text {b }}$ \\ University of Malaya
}

\begin{abstract}
This paper assesses the relationship between poverty on the one hand and economic growth and income inequality on the other hand by utilising a panel data set of 145 economies spanning the period, 1982 to 2017. The Arellano-Bond GMM estimation technique is employed to address the potential endogeneity problem in the regression exercise. In the course of the assessment, controls are effected for different country characteristics namely, income level and the degree of income inequality. Generally, it is found that economic growth and income inequality have a stronger bearing, negatively and positively respectively, on the incidence of poverty in middleincome than in low-income economies. The two variables also appear to have a larger impact in low-income inequality than in high-income inequality economies.
\end{abstract}

Keywords: Growth, inequality, poverty

JEL classification: 132, 010, 040, 047

\section{Introduction}

Poverty eradication is one of the major goals of public policy of many countries and international organisations. In recent decades, the living standards of a large part of the world's population have increased rapidly. According to data from the World Bank (2018), the levels of global poverty have been on a decline since the 1980s. The first target of the Millennium Development Goals (MDGs) which was set to halve the number of poor living below $\$ 1.90$ a day (2011 purchasing power parity (PPP)) was met five years ahead of the 2015 deadline (United Nations, 2013). The total number of poor living below \$1.90 a day (2011 PPP) has slackened from 1.9 billion in 1981 to 0.782 billion in 2013 (World Bank, 2018).

Given this scenario, the sustainable development goal (SDG) of ending extreme levels of poverty by 2030 appears reachable. However, progress in poverty reduction is uneven amongst countries. A lot of developing countries especially the low-income economies are still experiencing formidable challenges in poverty alleviation.

As shown in Figure 1, most of the poverty reductions in recent decades can be observed in middle-income economies. In contrast, the number of poor living below

a Faculty of Economics and Administration, University of Malaya, 50603 Kuala Lumpur, Malaysia. Email: dvdleow@gmail.com (Corresponding author)

b Faculty of Economics and Administration, University of Malaya, 50603 Kuala Lumpur, Malaysia. Email: tanec@um.edu.my

Article Info: Received 14 September 2018; Revised 14 May 2019; Accepted 28 August 2019 https://doi.org/10.22452/MJES.vol56no2.3 


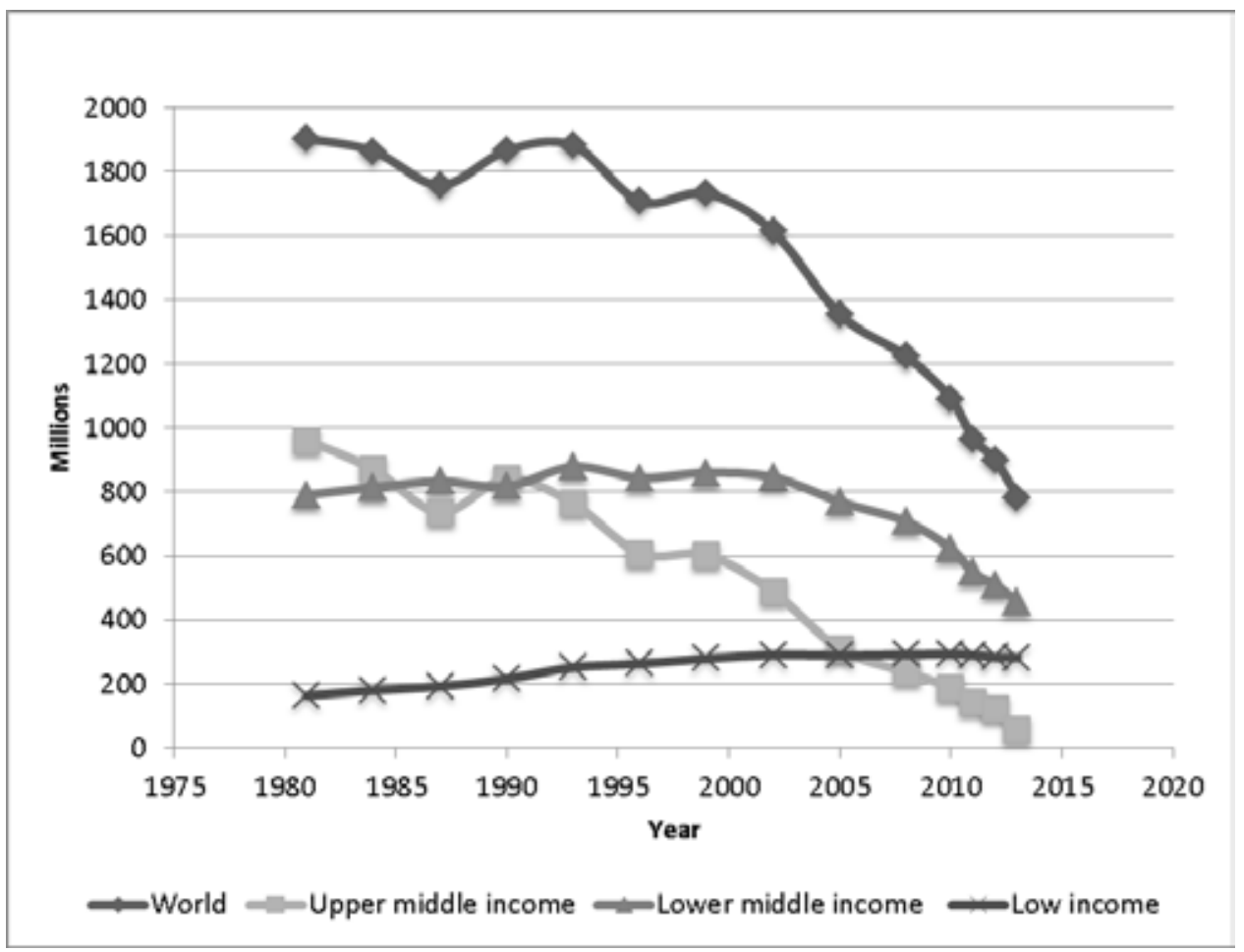

Figure 1. Number of poor living below $\$ 1.90$ a day (2011 PPP) Source: World Bank (2018), World Development Indicators (WDI).

$\$ 1.90$ a day (2011 PPP) in low-income economies rose from 163.8 million in 1981 to 283.0 million in 2013 (World Bank, 2018). There still exist unacceptable numbers of poor who cannot even secure the basic necessities of life.

Economic growth has commonly been viewed as an avenue for poverty reduction. Ravallion (2011) maintains that the remarkable economic growth in China, India and Brazil has contributed to their progress in fighting poverty. Most countries in Asia have transformed their economic structures from primary sector-based to industrial-based in the past few decades, enabling them to produce and export manufactured goods instead of primary commodities. This has facilitated their economic growth. In contrast, the sub-Saharan African countries have been displaying relatively slow growth of their predominantly primary sector-based economies.

Notwithstanding the above, there are many developing countries that have staged encouraging economic growth and yet have failed to witness any significant reduction in their poverty levels. One possible reason for this failure is that rapid economic growth has merely served to worsen income inequality in these countries. Rapid economic growth may only increase the number of billionaires in a country with very little benefits for low-income earners. Hence, income inequality could be another factor to be reckoned in the quest for reduced poverty. 
This paper attempts to strengthen the empirical literature on poverty in four major respects. First, unlike most past studies, in this study the relationship between poverty on the one hand and income inequality and economic growth on the other hand is estimated by controlling for the income level and for the degree of income inequality. Adams (2004) estimated the growth elasticity of poverty amongst lowincome and middle-income economies but did not consider high-income economies. This study is also more extensive than Adams (2004) as it includes more countries, more explanatory variables and a longer time span. Second, many previous studies (e.g. Adams, 2004; Easterly, 2000; Fosu, 2008; Nasir and Mridha, 2017) analysed the dynamic relationships amongst poverty, income inequality and economic growth using the pooled OLS, fixed effects and random effects estimation methods which fail to address the potential endogeneity problem in the estimated models. An endogeneity problem arises when changes in the explanatory variables are associated with the error term in the model, leading to inconsistent and biased parameter estimates. Therefore, this paper contributes to the empirical literature by employing a more appropriate estimation method, i.e. the Arellano-Bond generalized method of moments (GMM) to address the endogeneity issue. There exist recent studies on poverty, income inequality and economic growth (Agyemang, 2015; Amini \& Dal Bianco, 2016; Fosu, 2017) that employ the GMM method in regional analysis. However, these and other studies as highlighted in the next section are merely concerned about regional and individual country differences. This paper differs from theirs as it involves controlling for the income level and for the degree of income inequality. Third, this paper also differs from most previous studies as it accounts for the possible influences of unemployment and inflation on poverty. And fourth, the paper also applies an alternative measure of poverty based upon a poverty line of $\$ 3.20$ a day for regressions involving high-income economies instead of the mere $\$ 1.90$ per day measure.

The rest of this paper is structured as follows. A more extensive review of the literature is provided in the next section while the models for estimation and the empirical results are detailed in Section 3. The paper concludes with remarks in Section 4.

\section{Literature Review}

As highlighted in the preceding section, it is generally believed that economic growth could make an important contribution to poverty reduction. The association between poverty and economic growth in 16 developing countries in the 1980s is examined by Ravallion (1995). He finds that a $1 \%$ growth in per capita income could lead to a $3 \%$ reduction in the poverty headcount ratio. Similarly, the link between economic growth and poverty in 60 developing countries is analysed by Adams (2004) and it is found that economic growth could result in poverty reduction in most of the developing countries. The absolute magnitude of the negative growth effect on poverty would however vary with the yardstick used for measuring economic growth. The growth in GDP per capita has also been found by Wieser (2011) as one of the significant contributors to poverty reduction in 65 developing countries in the long run, with the growth elasticity of poverty reduction being independent of regions. That economic growth could be linked to poverty alleviation is also established as true in the case of 
28 EU member states by Michálek and Výboštok (2019). However, poverty is worsened as income inequality increases.

There are also country-specific papers. The relationship between poverty and economic growth in urban China is being studied by Meng, Gregory and Wang (2005) using income survey data from 1986 to 2000. It is discovered that average income growth is negatively related to the poverty rate in urban China, with a $1 \%$ increase in average income resulting in a $2.61 \%$ reduction of the poverty rate. The impact of economic growth on poverty in the United States is investigated by Stevans and Sessions (2008) over the period from 1959 to 1999. By employing the error-correction modelling technique, it is found that a long-run negative relationship exists between GDP growth and the poverty level in the United States. This could be due to the fact that the poor in the labour force have a greater chance of securing a job during periods of high economic growth. The impact of economic growth on poverty reduction in 16 African countries is studied by Fanta and Upadhyay (2009) based upon household survey data. It is found that income growth could alleviate poverty in those African countries with the estimated growth elasticity of poverty reduction ranging between $-0.5 \%$ and $-1.1 \%$.

Inequality in income distribution however could negate the poverty-reducing effect of economic growth. It is found by Fosu (2008), Ravallion and Chen (2007) and Easterly (2000) that although economic growth could reduce poverty levels, a high degree of income inequality could undermine the poverty eradication efforts. Economic growth may not be translated into reduced poverty in the presence of income inequality.

The relationship between poverty and economic growth in the United States of America is examined by Stevans and Sessions (2008) and it is found that middle and lower class households could not benefit from economic growth due to rising income inequalities in the country. Income growth is also found by Nasir and Mridha (2017) to eliminate poverty across the United States during 2006 to 2010. However, the results from their study also suggest that merely pro-growth policies are unlikely to ensure faster poverty reduction in the United States. The policy intervention must also focus on pro-poor growth strategies targeting the incomes of those in the lower quintiles. Income growth, inequality and poverty in Italy are also studied by Lombardo (2011) over the period, 1977-2004. It is found that while a $1 \%$ increase in mean income would reduce the poverty headcount by around $2.8 \%$, a $1 \%$ increase in income inequality would raise it by about $2.2 \%$.

The relationship among poverty, income inequality and economic growth in Latin American countries is investigated by De Janvry and Sadoulet (2000) over the period, 1970-1994. It is found that income growth could reduce poverty in both urban and rural areas. Additionally, it is found that income growth could significantly alleviate urban poverty particularly when the income inequality levels in those countries are low.

The influence of economic growth on poverty decline among 50 emerging and transitional economies (ETEs) is examined by Tridico (2010) over the period, 19952006. Although the average economic growth of these 50 countries was around $4.7 \%$ over that period, it failed to have any significant dampening impact on poverty. It is found by Agyemang (2015) that there is a greater economic growth effect on poverty reduction when the income inequality in the developing region is low than when it is 
high. Similarly, by studying poverty, inequality and growth in developing regions over the period of 1980-2007, it is found by Fosu (2017) that higher income amid lower income inequality in developing countries could imply greater ability to translate economic growth into poverty reduction. Poverty reduction in Mexico is found to be highly determined by income growth and income inequality in Mexico by IniguezMontiel and Kurosaki (2018). It is also found that inflation is highly detrimental to the poor in Mexico. Besides this, lower levels of income inequality could spur growth of the Mexican economy. This in turn contributes to further alleviation of income inequality.

\section{Model Specification and Estimation}

In order to re-examine the determinants of poverty, this paper adapts Wieser's (2011) specification of determinants of poverty by including lagged poverty and income inequality. The empirical equations for estimation are as follows:

$$
\begin{aligned}
& \text { In POV } \\
& \text { In } P O V_{i, t}=\beta_{0}+\beta_{1} \ln P O V_{i, t-1}+\beta_{2} \ln E_{i, t}+\beta_{3} \operatorname{In} I N E Q_{i, t}+\beta_{4} U_{i, t}+\beta_{5} I N F_{i, t}+\eta_{i, t}
\end{aligned}
$$

where $\ln =$ natural logarithm

POV = poverty level

$\mathrm{EG}=$ economic growth

INEQ = income inequality

UN = unemployment rate

INF = inflation rate

$\mathrm{i}$ and $\mathrm{t}$ are country and time subscripts respectively

$\varepsilon$ and $\eta$ are error terms and $\alpha$ 's and $\beta^{\prime}$ 's are the parameters to be estimated.

The poverty level (POV) is represented by the poverty headcount ratio defined as the share of the population whose incomes fall below a certain poverty line. In the course of estimating the equations, the poverty headcount ratio based upon the poverty line of S1.90 per day (2011 PPP) is relied upon, supplemented by another based upon $\$ 3.20$ per day (2011 PPP). The ratio based upon $\$ 1.90$ per day is applied in estimations for all economies regardless of income level while the ratio based upon $\$ 3.20$ per day is applied in supplementary estimations involving high-income economies. This is in view of the possibility that the former is more relevant to low- and middle-income economies while the latter may be more appropriate for high-income ones.

For economic growth (EG), it is approximated by GDP per capita growth unlike the use of survey mean income growth by Bourguignon (2004). The per capita GDP growth is commonly referred to in the economic growth literature and by policy-makers. Its estimated coefficient $\left(\alpha_{2}\right.$ or $\left.\beta_{2}\right)$ is expected to be negative. Following convention, the degree of income inequality (INEQ) is represented by the Gini coefficient and its estimated coefficient $\left(\alpha_{3}\right.$ or $\beta_{3}$ ) should be positive. As unemployment (UN) could adversely affect earnings capacities of people, it should have a positive estimated coefficient $\left(\beta_{4}\right)$. The figures for the rate of inflation (INF) are based upon the consumer price index. Given that a high inflation rate could heighten the cost of living and worsen poverty, its estimated coefficient $\left(\beta_{5}\right)$ should be positive. 
To estimate equations 1 and 2, an annual panel data set of 145 economies over the period from 1982 to 2017 which yields at most 1044 usable unbalanced panel observations is mobilised from the World Development Indicators (WDI) of the World Bank (2018). The choice of the 145 economies as listed in Table A1 in the appendix and the sample period is dictated by data availability. In estimating the equations, the paper controls interchangeably for the income levels and for the degree of income inequality by segregating economies into high-, middle- and low-income economies and into lowand high-income inequality economies. Note that the high-, middle- and low-income economies are defined as those with the latest GNI per capita of $\$ 12,056$ or more, between $\$ 996$ and $\$ 12,055$, and $\$ 995$ or less, respectively. The low-income inequality economies are defined as those with the latest GINI index of 30 or less while highincome inequality economies are those with the latest GINI index of 45 or more.

As for the estimation technique, to steer clear of the potential endogeneity problem, the generalized method of moments (GMM) technique as advanced by Arellano and Bond (1991) is employed. A lot of past studies merely employed the pooled ordinary least squares (POLS) technique, the fixed effects model (FEM) and the random effects model (REM). Hence their estimates could have suffered from the endogeneity problem. The Arellano-Bond (1991) estimator is valid on the assumptions of absence of serial correlation in the residuals and weak exogeneity of the lags of the explanatory variables (Baltagi, 2009, 2013; Law, 2018). However, to ensure the use of the GMM technique is valid, two preliminary tests are conducted namely, the Sargan's J-test and the Arellano-Bond serial correlation test. The Sargan's test involves testing the null hypothesis that the instruments that are being used are uncorrelated with the error term. Failure to reject the null hypothesis would imply that the instruments selected are valid for use in the GMM model (Gujarati \& Porter, 2009). On the other hand, the Arellano-Bond test is a test of the null hypothesis that there is no second-order serial correlation in the differenced error term. It is stressed by Chong and Gradstein (2007) that it is more important to determine whether there is second-order rather than firstorder serial correlation in the model. Acceptance of the null hypothesis would imply that the GMM estimator is consistent.

The GMM estimates of equations (1) and (2) based upon the poverty line of \$1.90 per day while controlling and not controlling for income levels are presented in Table 1. As indicated by the p-value of Sargan's J-statistics, the instruments used in the estimations are valid. Besides this, the Arellano-Bond test would suggest that the null hypothesis of no second-order serial correlation cannot be rejected. The coefficient of lagged poverty (POV $(-1))$ in most of the estimated equations except those of the high income economies is estimated to be positive and significantly different from zero at the $5 \%$ level. It appears that inflation has no bearing on poverty as its estimated coefficient is statistically insignificant in all cases. On the other hand, unemployment only has a bearing on poverty in low-income economies with an estimated coefficient of 3.201. Generally, income inequality and economic growth are important variables explaining poverty based upon the overall sample. However, it is interesting to note that these factors only matter in middle-income and low-income economies going by the statistical significance of all the estimated coefficients. Economic growth only has a poverty-reducing effect in middle-income (estimated coefficient $-0.339 /-0.414$ ) and low- 


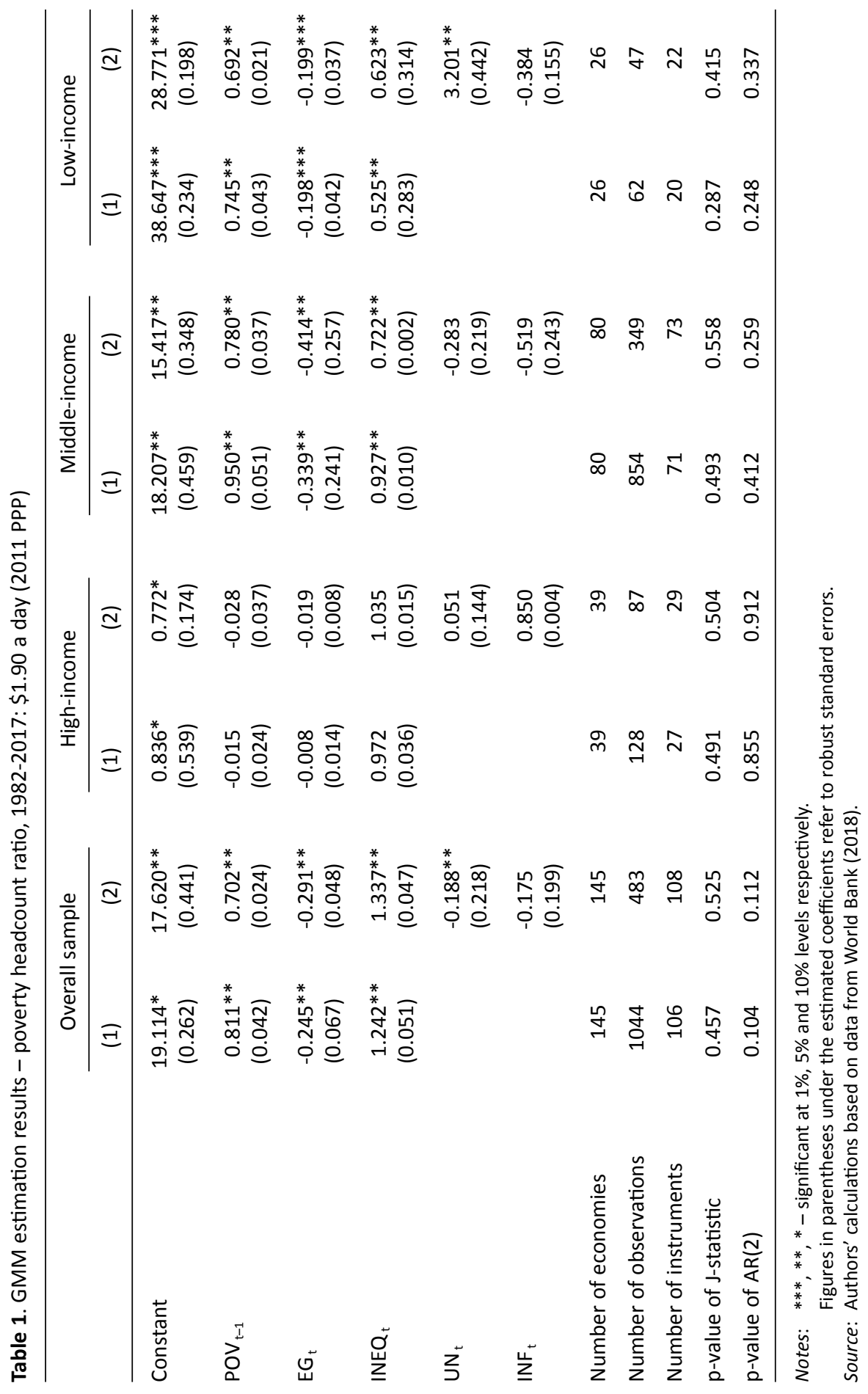


income (estimated coefficient $-0.198 /-0.199$ ) economies. The poverty-reducing effect of economic growth is thus stronger in middle-income than in low-income economies. Income inequality also seems to have a stronger positive bearing on poverty in middleincome economies (estimated coefficient 0.927/0.722) than in low-income (estimated coefficient $0.525 / 0.623$ ) economies. It should also be noted that the estimated coefficient of income inequality is much larger than the absolute value of the estimated coefficient of economic growth in both the middle- and low-income economies. This would imply that a decline in income inequality has a stronger poverty-reducing effect than economic growth.

As basing the poverty headcount ratio on the poverty line of $\$ 1.90$ per day may not be appropriate for high-income economies, equations (1) and (2) are also re-estimated based upon \$3.20 per day for these economies and the results are presented in Table 2. Based upon the p-value of Sargan's J-statistic and the Arellano-Bond second-order serial correlation test statistic, the estimates of equations (1) and (2) in Table 2 are valid. The lagged poverty coefficient is statistically significant at the $5 \%$ level. Contrary to the results based upon $\$ 1.90$ per day in Table 1 , the estimated coefficient of economic growth $(-0.053 /-0.079)$ and of income inequality (1.497/0.914) have turned out to be statistically significant at the $5 \%$ and the $1 \%$ level respectively. This suggests that economic growth and income inequality do have a bearing on poverty even in high-income economies.

Table 2. GMM estimation results - poverty headcount ratio, 1982-2017: $\$ 3.20$ a day (2011 PPP)

\begin{tabular}{lcc}
\hline & \multicolumn{2}{c}{ High-income } \\
\cline { 2 - 3 } & $(1)$ & $(2)$ \\
\hline Constant & $2.358^{* *}$ & $2.102^{* *}$ \\
& $(0.220)$ & $(0.186)$ \\
POV $_{\mathrm{t}-1}$ & $0.294^{* * *}$ & $0.211^{* * *}$ \\
$\mathrm{EG}_{\mathrm{t}}$ & $(0.009)$ & $(0.017)$ \\
& $-0.053^{* *}$ & $-0.079^{* *}$ \\
INEQ $_{\mathrm{t}}$ & $(0.013)$ & $(0.009)$ \\
& $1.497^{* * *}$ & $0.914^{* * *}$ \\
$\mathrm{UN}_{\mathrm{t}}$ & $(0.011)$ & $(0.002)$ \\
& & 0.012 \\
INF $_{\mathrm{t}}$ & & $(0.010)$ \\
& & 1.041 \\
Number of economies & & $(0.055)$ \\
Number of observations & 39 & 39 \\
Number of instruments & 128 & 87 \\
$p$-value of J-statistic & 27 & 29 \\
$p$-value of AR(2) & 0.288 & 0.310 \\
\hline
\end{tabular}

Notes: $\quad * * *, * *, *-$ significant at $1 \%, 5 \%$ and $10 \%$ levels respectively. Figures in parentheses under the estimated coefficients refer to robust standard errors. Source: Authors' calculations based on data from World Bank (2018). 
The results of estimating equations (1) and (2) while controlling for the degree of income inequality are presented in Table 3. The estimation is carried out in terms of two alternative poverty headcount ratios corresponding with the poverty lines of $\$ 1.90$ per day and of $\$ 3.20$ per day. Based upon the p-value of Sargan's J-statistics and the Arellano-Bond second-order serial correlation test, all the estimates of equations (1) and (2) in Table 2 are valid and can be relied upon for inference-making. The estimated lagged poverty coefficient is also statistically significant at below $10 \%$ generally. Going by the magnitude and the statistical significance of the estimated coefficients, economic growth has a stronger dampening impact on poverty in low-income inequality (estimated coefficient $-0.178 /-0.133$ ) than in high-income inequality economies (estimated coefficient $-0.029 /-0.012$ ) in terms of the poverty line of $\$ 1.90$ per day. So is income inequality yielding a stronger worsening impact on poverty in the low-income inequality economies (estimated coefficient 0.835/0.997) than in high-income inequality economies (estimated coefficient 0.257/0.292). Generally parallel results are derived based upon the poverty line of $\$ 3.20$ per day. Moreover, unemployment in high-income inequality economies has a bearing on poverty in terms of both poverty measures with an estimated coefficient of $0.952 / 0.918$. Given such a magnitude, it can be deduced that unemployment has a stronger bearing on poverty than economic growth and income inequality in high income inequality economies.

Finally, as the results of the GMM might be sensitive to the number of lags of the dependent variable specified, equations (1) and (2) have been re-estimated by including two additional lags namely, POV(-2) and POV(-3) as a robustness check. This is only attempted for the overall sample and based only upon the poverty line of $\$ 1.90$ per day due to data constraints. The results of this re-estimation are shown in Table A2 in the appendix. Generally, they suggest that the two additional lag coefficients are statistically insignificant at the $5 \%$ level based upon equation (1). ${ }^{1}$ The estimated coefficients of the main variables of concern namely economic growth and income inequality generally remain significant.

\section{Concluding Remarks}

The primary purpose of this paper is to estimate the effects of economic growth and income inequality on the incidence of poverty by controlling for the economies' income levels and for their degrees of income inequality. Towards this end, the GMM technique is applied to a panel data set of 145 economies, spanning the period from 1982 through 2017. Two poverty headcount ratios are used to measure the incidence of poverty namely, one that is based upon the poverty line of $\$ 1.90$ per day and another, based upon $\$ 3.30$ per day which is particularly relevant to high-income economies.

As the review of the literature suggests, economic growth has been commonly viewed as an avenue for poverty reduction though its poverty-reducing effect could be negated by inequality in income distribution. This is confirmed to be true for all economies irrespective of income level by this more rigorous study. Hence, economic

\footnotetext{
1 The estimates of equation (2) are not valid as they could not withstand the Sargan test.
} 


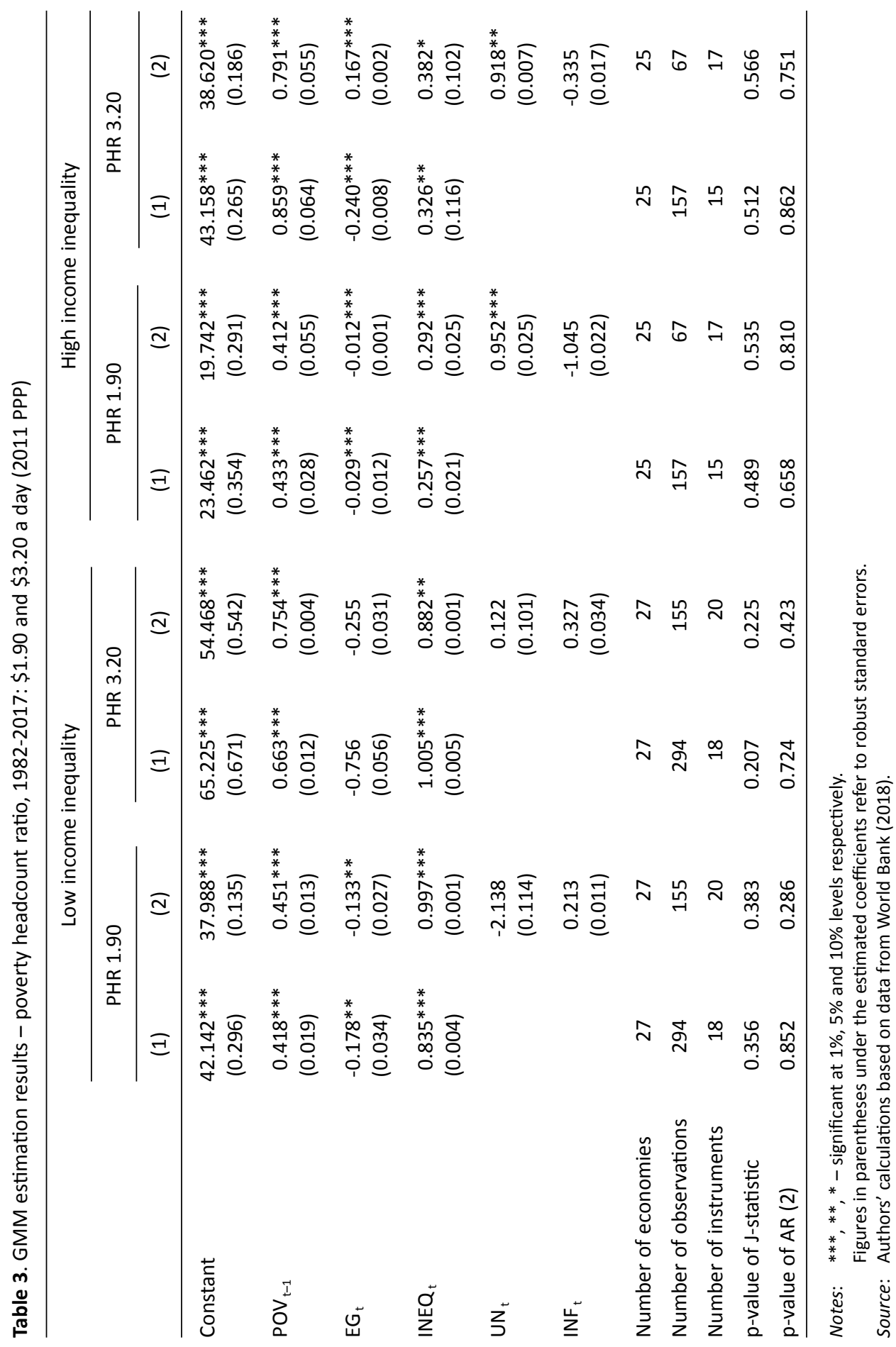


growth and income inequality are important factors to be considered by policy-makers in fighting poverty. However, this study also suggests that policy-makers should pay heed to the problem of income inequality as well in battling poverty as a decline in income inequality is found to have a stronger poverty-reducing effect than economic growth in all the economies. While economic growth in terms of per capita GDP has to be boosted, the problem of skewed income distribution has to be redressed.

It is also interesting to note from the empirical results that economic growth could bring about greater poverty reduction in middle-income than in low-income economies. This could generally be due to the existence of more superior production and infrastructure networks in middle-income economies such that the gains from economic growth could be trickled down easily to those at the lower rung of the social hierarchy.

Similarly, the results suggest that an increase in income inequality could worsen poverty more in middle-income than in low-income economies. This could be due to lesser governmental focus upon socioeconomic problems in middle-income than in lowincome economies. However, it is possible that any effort to redress income inequality could precipitate a greater decline in poverty in middle-income than in low-income economies. This is by virtue of the possibility that any income redistribution policy would entail a greater volume of income being transferred to the poor in a middleincome than in a low-income country.

Going by the classification of economies by degree of income inequality, this study finds that economic growth has a stronger dampening impact on poverty in lowincome inequality economies than in high-income inequality economies, consistent with other earlier studies. However, this study additionally shows that income inequality could contribute more to poverty in the former than in the latter. This is rather an interesting finding, plausibly due to less attention being paid by governments in lowincome inequality economies to fight poverty. In other words, there could be a lack of sense of urgency on the part of governments to address socioeconomic issues in those economies.

\section{References}

Adams Jr., R.H. (2004). Economic growth, inequality and poverty: Estimating the growth elasticity of poverty. World Development, 32(12), 1989-2014. https://doi.org/10.1016/j.worlddev.2004.08.006

Agyemang, E. (2015). Economic growth, income inequality and poverty reduction: A regional comparative analysis (Doctoral dissertation, University of Lethbridge, Canada). Retrieved from https://opus.uleth.ca/bitstream/handle/10133/3635/AGYEMANG_ERIC_MA_2014.pdf

Amini, C., \& Dal Bianco, S. (2016). Poverty, growth, inequality and pro-poor factors: New evidence from macro data. Journal of Developing Areas, 50(2), 231-254. https://doi.org/10.1353/ jda.2016.0080

Arellano, M., \& Bond, S. (1991). Some tests of specification for panel data: Monte Carlo evidence and an application to employment equations. Review of Economic Studies, 58(2), 277-297. https://doi.org/ https://doi.org/10.2307/2297968

Baltagi, B.H. (2009). A companion to econometric analysis of panel data. Chichester, England: John Wiley \& Sons Ltd. 
Baltagi, B.H. (2013). Econometric analysis of panel data (5th ed.). Chichester, England: John Wiley \& Sons Ltd.

Bourguignon, F. (2004). The poverty-growth-inequality triangle. Poverty, Inequality and Growth, 69, 69-73.

Chong, A., \& Gradstein, M. (2007). Inequality and informality. Journal of Public Economics, 91(12), 159-179. https://doi.org/10.1016/j.jpubeco.2006.08.001

De Janvry, A., \& Sadoulet, E. (2000). Rural poverty in Latin America: Determinants and exit paths. Food Policy, 25(4), 389-409. https://doi.org/10.1016/S0306-9192(00)00023-3

Easterly, W. (2000). The effect of IMF and World Bank programs on poverty. Social Science Research Network Electronic Paper Collection, 1-31. https://doi.org/ 10.2139/ssrn.256883

Fanta, F., \& Upadhyay, M.P. (2009). Poverty reduction, economic growth and inequality in Africa. Applied Economics Letters, 16(18), 1791-1794. https://doi.org/10.1080/13504850701719587

Fosu, A.K. (2008). Inequality and the growth-poverty nexus: Specification empirics using African data. Applied Economics Letters, 15(7), 563-566. https://doi.org/10.1080/13504850 600706669

Fosu, A.K. (2017). Growth, inequality, and poverty reduction in developing countries: Recent global evidence. Research in Economics, 71(2), 306-336. https://doi.org/10.1016/j.rie. 2016.05.005

Gujarati, D.N., \& Porter, D.C. (2009). Basic econometrics (5th ed.). Boston, MA: McGraw-Hill.

Iniguez-Montiel, A.J., \& Kurosaki, T. (2018). Growth, inequality and poverty dynamics in Mexico. Latin American Economic Review, 27(12), 1-25. https://doi.org/10.1186/s40503-018-0058-9

Law, S.H. (2018). Applied panel data analysis: Short panels. Serdang, Malaysia: Universiti Putra Malaysia Press.

Lombardo, V. (2011). Growth and inequality effects on poverty reduction in Italy. Rivista Italiana degli Economisti, 16(2), 241-280.

Michálek, A., \& Výboštok, J. (2019). Economic growth, inequality and poverty in the EU. Social Indicators Research, 141(2), 611-630. https://doi.org/10.1007/s11205-018-1858-7

Meng, X., Gregory, R., \& Wang, Y. (2005). Poverty, inequality, and growth in urban China, 19862000. Journal of Comparative Economics, 33(4), 710-729. https://doi.org/10.1016/j.jce. 2005.08.006

Nasir, A.B.M., \& Mridha, H.A. (2017). Does income inequality dampen growth effect on poverty? Evidence from the US county data. Journal of Developing Areas, 51(4), 167-177. https://doi. org/10.1353/jda.2017.0095

Ravallion, M. (1995). Growth and poverty: Evidence for developing countries in the 1980s. Economics Letters, 48(3-4), 411-417. https://doi.org/10.1016/0165-1765(94)00620-H

Ravallion, M. (2011). A comparative perspective on poverty reduction in Brazil, China and India. World Bank Research Observer, 26(1), 71-104.

Ravallion, M., \& Chen, S. (2007). China's (uneven) progress against poverty. Journal of Development Economics 82(1), 1-42. https://doi.org/10.1016/j.jdeveco.2005.07.003

Stevans, L.K., \& Sessions, D.N. (2008). The relationship between poverty and economic growth revisited. Journal of Income Distribution, 17(1), 5-20.

Tridico, P. (2010). Growth, inequality and poverty in emerging and transition economies. Transition Studies Review, 16(4), 979-1001. https://doi.org/10.1007/s11300-009-0116-8

United Nations. (2013). The Millennium Development Goals Report 2013. New York, NY: United Nations Development Programme.

Wieser, C. (2011). Determinants of the growth elasticity of poverty reduction. Why the impact on poverty reduction is large in some developing countries and small in others (WIFO Working Papers, No. 406). Vienna: Austrian Institute of Economic Research (WIFO).

World Bank (2018). World Development Indicators (WDIs) 2018. Washington DC: Author. 


\section{Appendices}

Table A1. List of economies

\begin{tabular}{|c|c|c|c|c|c|}
\hline Economies & $\begin{array}{c}\text { High } \\
\text { income }\end{array}$ & $\begin{array}{l}\text { Middle } \\
\text { income }\end{array}$ & $\begin{array}{c}\text { Low } \\
\text { income }\end{array}$ & $\begin{array}{c}\text { High } \\
\text { inequality }\end{array}$ & $\begin{array}{c}\text { Low } \\
\text { inequality }\end{array}$ \\
\hline Albania & & v & & & $v$ \\
\hline Algeria & & v & & & $v$ \\
\hline Angola & & v & & & \\
\hline Argentina & $v$ & & & & \\
\hline Armenia & & v & & & $\mathrm{v}$ \\
\hline Australia & v & & & & \\
\hline Austria & $v$ & & & & $v$ \\
\hline Azerbaijan & & v & & & $v$ \\
\hline Bangladesh & & v & & & $v$ \\
\hline Belarus & & v & & & v \\
\hline Belgium & $v$ & & & & $v$ \\
\hline Belize & & v & & & \\
\hline Benin & & & v & v & \\
\hline Bhutan & & v & & & \\
\hline Bolivia & & v & & & \\
\hline Bosnia and Herzegovina & & $v$ & & & $v$ \\
\hline Botswana & & $v$ & & $v$ & \\
\hline Brazil & & v & & $v$ & \\
\hline Bulgaria & & v & & & \\
\hline Burkina Faso & & & v & & \\
\hline Burundi & & & V & & \\
\hline Cabo Verde & & v & & v & \\
\hline Cameroon & & v & & $v$ & \\
\hline Canada & $v$ & & & & \\
\hline Central African Republic & & & v & v & \\
\hline Chad & & & $v$ & & \\
\hline Chile & v & & & V & \\
\hline China & & v & & & \\
\hline Colombia & & v & & $v$ & \\
\hline Comoros & & & $\mathrm{v}$ & v & \\
\hline Congo, Dem. Rep. & & & $v$ & & \\
\hline Congo, Rep. & & v & & v & \\
\hline Costa Rica & & v & & v & \\
\hline Cote d'Ivoire & & v & & & \\
\hline Croatia & v & & & & \\
\hline Cyprus & v & & & & \\
\hline Czech Republic & v & & & & v \\
\hline Denmark & $v$ & & & & v \\
\hline Dominican Republic & & v & & v & \\
\hline Ecuador & & v & & & \\
\hline Egypt, Arab Rep. & & v & & & \\
\hline El Salvador & & v & & & \\
\hline Estonia & $\checkmark$ & & & & \\
\hline Ethiopia & & & v & & \\
\hline
\end{tabular}


Table A1. Continued

\begin{tabular}{|c|c|c|c|c|c|}
\hline Economies & $\begin{array}{c}\text { High } \\
\text { income }\end{array}$ & $\begin{array}{l}\text { Middle } \\
\text { income }\end{array}$ & $\begin{array}{c}\text { Low } \\
\text { income }\end{array}$ & $\begin{array}{c}\text { High } \\
\text { inequality }\end{array}$ & $\begin{array}{c}\text { Low } \\
\text { inequality }\end{array}$ \\
\hline Fiji & & v & & & \\
\hline Finland & v & & & & $\checkmark$ \\
\hline France & $\checkmark$ & & & & \\
\hline Gabon & & v & & & \\
\hline Gambia, The & & & $v$ & & \\
\hline Georgia & & $v$ & & & \\
\hline Germany & 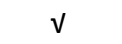 & & & & \\
\hline Ghana & & v & & & \\
\hline Greece & v & & & & \\
\hline Guatemala & & v & & v & \\
\hline Guinea & & & $v$ & & \\
\hline Guinea-Bissau & & & v & v & \\
\hline Honduras & & v & & v & \\
\hline Hungary & v & & & & \\
\hline Iceland & v & & & & v \\
\hline India & & v & & & \\
\hline Indonesia & & v & & & \\
\hline Iran, Islamic Rep. & & v & & & \\
\hline Iraq & & v & & & v \\
\hline Ireland & $v$ & & & & \\
\hline Israel & v & & & & \\
\hline Italy & v & & & & \\
\hline Jamaica & & v & & v & \\
\hline Jordan & & v & & & \\
\hline Kazakhstan & & v & & & v \\
\hline Kenya & & $v$ & & & \\
\hline Korea, Rep. & $\checkmark$ & & & & \\
\hline Kosovo & & v & & & v \\
\hline Kyrgyz Republic & & v & & & v \\
\hline Lao PDR & & v & & & \\
\hline Latvia & 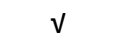 & & & & \\
\hline Lesotho & & v & & v & \\
\hline Liberia & & & v & & \\
\hline Lithuania & v & & & & \\
\hline Luxembourg & v & & & & \\
\hline Madagascar & & & $\mathrm{v}$ & & \\
\hline Malawi & & & v & & \\
\hline Malaysia & & v & & & \\
\hline Maldives & & v & & & \\
\hline Mali & & & v & & \\
\hline Malta & v & & & & v \\
\hline Mauritania & & v & & & \\
\hline Mauritius & & $v$ & & & \\
\hline Mexico & & v & & & \\
\hline Micronesia, Fed. Sts. & & $v$ & & & \\
\hline Moldova & & $v$ & & & $\checkmark$ \\
\hline
\end{tabular}


Table A1. Continued

\begin{tabular}{|c|c|c|c|c|c|}
\hline Economies & $\begin{array}{c}\text { High } \\
\text { income }\end{array}$ & $\begin{array}{l}\text { Middle } \\
\text { income }\end{array}$ & $\begin{array}{c}\text { Low } \\
\text { income }\end{array}$ & $\begin{array}{c}\text { High } \\
\text { inequality }\end{array}$ & $\begin{array}{c}\text { Low } \\
\text { inequality }\end{array}$ \\
\hline Mongolia & & v & & & \\
\hline Montenegro & & $v$ & & & \\
\hline Morocco & & $\mathrm{v}$ & & & \\
\hline Mozambique & & & & $\checkmark$ & \\
\hline Namibia & & $\checkmark$ & & $\checkmark$ & \\
\hline Nepal & & & $\checkmark$ & & \\
\hline Netherlands & $v$ & & & & $v$ \\
\hline Nicaragua & & $\checkmark$ & & $\checkmark$ & \\
\hline Niger & & & $\checkmark$ & & \\
\hline Nigeria & & $\checkmark$ & & & \\
\hline Norway & v & & & & v \\
\hline Pakistan & & v & & & \\
\hline Panama & v & & & v & \\
\hline Papua New Guinea & & $\checkmark$ & & & \\
\hline Paraguay & & $\checkmark$ & & v & \\
\hline Peru & & v & & & \\
\hline Philippines & & v & & & \\
\hline Poland & v & & & & \\
\hline Portugal & $v$ & & & & \\
\hline Romania & & v & & & \\
\hline Russian Federation & & v & & & \\
\hline Rwanda & & & $v$ & & \\
\hline Samoa & & $\checkmark$ & & & \\
\hline Senegal & & & v & & \\
\hline Serbia & & v & & & v \\
\hline Sierra Leone & & & $\checkmark$ & & \\
\hline Slovak Republic & $v$ & & & & v \\
\hline Slovenia & v & & & & v \\
\hline Solomon Islands & & v & & & \\
\hline South Africa & & $v$ & & v & \\
\hline Spain & $v$ & & & & \\
\hline Sri Lanka & & v & & & \\
\hline St. Lucia & & v & & & \\
\hline Sweden & $v$ & & & & v \\
\hline Switzerland & 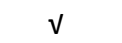 & & & & \\
\hline Tajikistan & & & v & & \\
\hline Tanzania & & & v & & \\
\hline Thailand & & v & & & \\
\hline Timor-Leste & & $\checkmark$ & & & v \\
\hline Togo & & & v & & \\
\hline Tonga & & v & & & \\
\hline Trinidad and Tobago & v & & & & \\
\hline Tunisia & & v & & & \\
\hline Turkey & & v & & & \\
\hline Uganda & & & v & & \\
\hline Ukraine & & v & & & v \\
\hline
\end{tabular}


Table A1. Continued

\begin{tabular}{|c|c|c|c|c|c|}
\hline Economies & $\begin{array}{c}\text { High } \\
\text { income }\end{array}$ & $\begin{array}{l}\text { Middle } \\
\text { income }\end{array}$ & $\begin{array}{l}\text { Low } \\
\text { income }\end{array}$ & $\begin{array}{c}\text { High } \\
\text { inequality }\end{array}$ & $\begin{array}{c}\text { Low } \\
\text { inequality }\end{array}$ \\
\hline United Kingdom & $\sqrt{ }$ & & & & \\
\hline United States & $\sqrt{ }$ & & & & \\
\hline Uruguay & $\sqrt{ }$ & & & & \\
\hline Uzbekistan & & $\sqrt{ }$ & & & \\
\hline Venezuela, RB & & $\sqrt{ }$ & & $\sqrt{ }$ & \\
\hline Vietnam & & $\sqrt{ }$ & & & \\
\hline West Bank and Gaza & & $\sqrt{ }$ & & & \\
\hline Yemen, Rep. & & & $\sqrt{ }$ & & \\
\hline Zambia & & $\sqrt{ }$ & & $v$ & \\
\hline
\end{tabular}

Source: World Bank (2018).

Table A2. GMM estimation results considering the inclusion of additional lags of the dependent variable - poverty headcount ratio, 1982-2017: \$1.90 a day (2011 PPP)

\begin{tabular}{|c|c|c|c|c|}
\hline & \multicolumn{2}{|c|}{ All samples } & \multicolumn{2}{|c|}{ All samples } \\
\hline & (1) & (2) & (1) & (2) \\
\hline Constant & $\begin{array}{c}32.537^{* *} \\
(0.183)\end{array}$ & $\begin{array}{l}41.836 * * \\
(0.523)\end{array}$ & $\begin{array}{c}28.808 * * \\
(0.119)\end{array}$ & $\begin{array}{l}34.094 * * \\
(0.229)\end{array}$ \\
\hline $\mathrm{POV}_{\mathrm{t}-1}$ & $\begin{array}{c}1.216^{* *} \\
(0.038)\end{array}$ & $\begin{array}{c}0.431^{* *} \\
(0.053)\end{array}$ & $\begin{array}{c}0.638 * * \\
(0.057)\end{array}$ & $\begin{array}{c}0.597 * * \\
(0.042)\end{array}$ \\
\hline $\mathrm{POV}_{\mathrm{t}-2}$ & $\begin{array}{l}-0.037 \\
(0.085)\end{array}$ & $\begin{array}{l}-0.314 \\
(0.041)\end{array}$ & $\begin{array}{l}-0.045 \\
(0.072)\end{array}$ & $\begin{array}{l}-0.001 \\
(0.067)\end{array}$ \\
\hline $\mathrm{POV}_{\mathrm{t}-3}$ & & & $\begin{array}{l}-0.170 \\
(0.081)\end{array}$ & $\begin{array}{l}-0.005 \\
(0.060)\end{array}$ \\
\hline $\mathrm{EG}_{\mathrm{t}}$ & $\begin{array}{c}0.707^{*} \\
(0.165)\end{array}$ & $\begin{array}{c}-0.064^{*} \\
(0.089)\end{array}$ & $\begin{array}{c}0.989 \\
(0.162)\end{array}$ & $\begin{array}{l}-1.071^{*} \\
(0.156)\end{array}$ \\
\hline $\mathrm{INEQ}_{\mathrm{t}}$ & $\begin{array}{c}0.748^{*} \\
(0.001)\end{array}$ & $\begin{array}{l}0 . .852^{* *} \\
(0.249)\end{array}$ & $\begin{array}{c}0.763^{*} \\
(0.014)\end{array}$ & $\begin{array}{c}0.663^{*} \\
(0.015)\end{array}$ \\
\hline $\mathrm{UN}_{\mathrm{t}}$ & & $\begin{array}{c}-0.828^{*} \\
(0.001)\end{array}$ & & $\begin{array}{l}-4.189 \\
(0.053)\end{array}$ \\
\hline $\mathrm{INF}_{\mathrm{t}}$ & & $\begin{array}{c}0.052 \\
(0.118)\end{array}$ & & $\begin{array}{c}0.113 \\
(0.250)\end{array}$ \\
\hline Number of economies & 31 & 31 & 14 & 14 \\
\hline Number of observations & 153 & 112 & 67 & 51 \\
\hline Number of instruments & 31 & 31 & 27 & 29 \\
\hline$p$-value of $\mathrm{J}$-statistic & 0.183 & 0.025 & 0.171 & 0.012 \\
\hline$p$-value of $A R(2)$ & 0.263 & 0.238 & 0.302 & 0.105 \\
\hline
\end{tabular}

Notes: $* *, *-$ significant at $5 \%$ and $10 \%$ levels respectively.

Figures in parentheses under the estimated coefficients refer to robust standard errors.

Source: Authors' calculations based on data from World Bank (2018). 